Abigail Jacobson

\title{
NEGOTIATING OTTOMANISM IN TIMES \\ OF WAR: JERUSALEM DURING WORLD WAR I THROUGH THE EYES OF A LOCAL MUSLIM RESIDENT
}

Through a microanalysis of a diary written by Ihsan Tourjman during World War I, this article explores how the Arab-Ottoman elite in Jerusalem experienced and viewed the war and perceived their own position within the Ottoman Empire. It focuses on the ways multilayered levels of identity were negotiated and debated following internal and external changes taking place at the time. The diary serves as a unique and valuable testimony that sheds light on life in Jerusalem at a critical period in the city's (and region's) history. Through close reading of this diary and other sources, this essay investigates how economic and social crises affected city residents and scrutinizes how political changes, as well as Ottoman policies and treatment of the local population, affected how individuals placed themselves within the context of the empire. 